\section{Integrated and Organic Fruit Production Systems for 'Liberty' Apple in the Northeast United States: A Systems-based Evaluation}

\author{
Gregory M. Peck ${ }^{1}$, Ian A. Merwin, and Michael G. Brown \\ Department of Horticulture, Cornell University, 134A Plant Science, Ithaca, \\ NY 14853
}

\author{
Arthur M. Agnello \\ Department of Entomology, New York State Agricultural Experiment Station, \\ Cornell University, Geneva, NY 14456
}

Additional index words. Environmental Impact Quotient (EIQ), kaolin clay, Malus $\times$ domestica Borkh., orchard, pesticide use, sustainable agriculture, systems research

\begin{abstract}
A systems-based approach was used to evaluate integrated (IFP) and organic fruit production (OFP) (during and after the transition period) in an established highdensity commercial orchard of disease-resistant 'Liberty' apples (Malus $\times$ domestica Borkh.). Agroecological and economic evaluations included: yields, tree growth, leaf nutrient levels, arthropod and cosmetic fruit damage, environmental impacts, variable costs of production, and potential crop value using both direct market and wholesale market prices. Cumulative yields (2004-2007) of both harvested and total (harvested + dropped) fruit were not different between the two systems. Tree size (trunk crosssectional area) was not consistently different between the production systems. The IFPgrown apples had between $3 \%$ and $6 \%$ insect damage (within normal percentages for this region) and between $3 \%$ and $17 \%$ total damage (either internal or cosmetic). The OFPgrown apples had between $3 \%$ and $25 \%$ insect damage and $3 \%$ to $75 \%$ total damage, varying greatly from year to year. In 2006, superficial blemishes, caused by diseases and scarfskin, were extensive on OFP-grown fruit. Using the Environmental Impact Quotient, the potential negative environmental impacts were estimated to be six times greater in the OFP system, largely as a result of the use of lime sulfur and fish oil for thinning and the large quantity of kaolin clay used for pest control. Partial budgets of both systems estimated variable production expenses to be $9 \%$ greater for OFP. Sales value was estimated to be $6 \%$ greater for OFP than IFP using direct market prices (e.g., farm stand or farmers' market) and $11 \%$ greater for IFP than OFP using wholesale market prices. A 56\% premium was used to calculate the OFP crop value in the third and fourth years (fruit could have been sold with an organic label after 36 months from the last organically prohibited material). Four years of evaluation suggested that IFP could be widely implemented in the northeastern United States, but the lack of market incentives might impede its adoption. Producing disease-resistant apples under an OFP system also showed potential for success, but a price premium would be needed to offset the reduced profitability incurred from arthropod pests, poor fruit finish, and small fruit size.
\end{abstract}

Extensive disease and arthropod problems, in addition to tree nutrition and crop load adjustment, pose barriers to adoption of integrated (IFP) and organic fruit production

Received for publication 8 Feb. 2010. Accepted for publication 3 May 2010.

Funding for this work was provided by USDA IREE Competitive Grants Program, Hatch Act funds, The Toward Sustainability Foundation of Marblehead MA, and the Cornell University Department of Horticulture.

Product donations were provided by Kreher Poultry Farm, The Mosaic Company, and Northwest Agricultural Products. Special thanks to Hugh Ink and the Cornell Orchards crew, Kristine Averill, and Emily Vollmer. Dr. Gerald White generously assisted with the economic analyses, and Françoise Vermeylen assisted with statistical analyses.

${ }^{1}$ To whom reprint requests should be addressed; e-mailgmp32@cornell.edu. cultivators, chemical thinning strategies, and foliar nutrient formulations. The confluence of these factors could increase the potential for IFP and OFP systems in humid growing regions.

The International Organization for Biocontrol (IOBC) defined IFP as "the economical production of high quality fruit, giving priority to ecologically safer methods, minimizing the undesirable side effects and use of agrochemicals, to enhance the safeguards to the environment and human health" (Anonymous, 2002). More specifically, IFP is a science-based system that uses biological and chemical pest controls based on monitoring to assess damage-action thresholds, selection of disease-resistant and locally adapted fruit and rootstock cultivars, strict limits on fertilizer applications determined by crop nutrient status and soil fertility tests, a short list of permissible and restricted pesticides, and on-farm inspections to certify that growers are following IFP regulations. Many IFP guidelines comply with GAP (Good Agricultural Practices) certification systems that are a requirement of many European retailers (Carroll and Robinson, 2004). This has fostered the widespread adoption of IFP in much of western Europe as well as in New Zealand, Chile, Australia, and other countries exporting to Europe. Despite being the standard method for apple production in many parts of the world, IFP has not been widely practiced in the United States. To help New York growers access these export markets, Cornell University recently developed an IFP protocol based on IOBC standards (Carroll and Robinson, 2006).

Organic agriculture, as defined by the U.S. Department of Agriculture (USDA) National Organic Program (NOP), also places strong emphasis on ecological farming methods (Federal Register, 2000). However, the NOP restricts inputs to those that are derived from natural substances such as manure-based fertilizers and pesticides derived from biological or mineral sources. A 36-month transition period and the development of a farm plan for nutrition and pest management are additional requirements under the NOP. Most OFP in the United States is located in arid, inland valleys of the West Coast, where disease and arthropod pests are relatively few and can be managed without synthetic pesticides. Granatstein and Kirby (2008) reported that $4.5 \%$ of Washington State's apple orchards (greater than 3080 ha) are under organic management and that production was expected to double by 2009 . Although New York is the second largest U.S. producer of apples (after Washington), less than $0.5 \%$ of New York's apple production $(\approx 50 \mathrm{ha})$ is organically certified (Merwin et al., 2005).

Disease control contributes greatly to pesticide use in New York's apple orchards with over $5.6 \times 10^{5} \mathrm{~kg}$ of fungicides being applied annually (USDA NASS, 2006). One approach for reducing the quantity of pesticides needed in apple production is to grow 
cultivars developed specifically for disease resistance, particularly to apple scab [Venturia inaequalis (Cooke) G. Wint.], one of the most common and severe apple diseases in humid growing regions. When scab-susceptible cultivars are used in OFP systems (where the use of synthetic fungicides is not permitted), the use of sulfur, copper, and lime sulfur may increase the total amount (by weight) of applied fungicides compared with conventional systems (Kovach et al., 1992). Breeding scab-resistant apples began in the 1940 s, and dozens of high-quality scab-resistant cultivars are now commercially available (Jönsson and Nybom, 2006; Merwin et al., 1994). One of the better known scabresistant cultivars, Liberty ('Macoun' $\times$ Purdue 54-12), has functional immunity to apple scab (based on the Vf gene) and resistance to fire blight [Erwinia amylovora (Burrill) Winslow et al.], cedar apple rust (Gymnosporangium juniperi-viginianae Schwein), and powdery mildew [Podosphaera leucotricha (Ellis \& Everh.) E. S. Salmon], thus making it an excellent cultivar for both IFP and OFP (Ellis et al., 1998; Lamb et al., 1978).

There is little understanding of how IFP or OFP systems affect orchard agroecosystems in the northeastern United States (Merwin et al., 2005). Research in arid climates has indicated that organic apple orchards could be more profitable, sustainable, and have improved fruit quality and nutritional content compared with integrated and conventional systems (Peck et al., 2006; Reganold et al., 2001). Studies in New Zealand and Iowa have shown that pest pressure in humid environments may be a serious impediment to these production systems and that better pest management with new materials will be needed (Delate et al., 2008; Suckling et al., 1999). Additionally, OFP has led to smaller fruit, which can potentially reduce market value (Delate et al., 2008; Peck et al., 2006; Reganold et al., 2001).

In this study, we compared IFP with the more widely recognized OFP system during and after the 36-month transition from conventional management. This systems-level project was conducted in a 'Liberty' apple orchard under humid growing conditions. Both systems used published certification protocols and recent advances in IPM, groundcover management, pesticides, machinery, and crop load management techniques. The objective of this study was to compare yields, tree growth, fruit damage, economics, and environmental impacts between IFP and OFP management.

\section{Materials and Methods}

Study location and experimental design. The experiment was located in a 0.42-ha block of high-density (1537 trees/ha; $1.5 \mathrm{~m}$ between trees; $4.3 \mathrm{~m}$ between rows; $2.7 \mathrm{~m}$ tall) 'Liberty'/'M.9' apple trees at the Cornell Orchards in Ithaca, NY (long. $42^{\circ} 26^{\prime} \mathrm{N}$, lat. $76^{\circ} 27^{\prime} \mathrm{W}$ ). The soil was a Collamer silty clay loam series (fine-silty, mixed, active, mesic
Glossaquic) formed from glacial lacustrine sediments. Baseline samples at the outset of the experiment (May 2004) showed that soil nutrient availability, organic matter $(3 \%)$, and $\mathrm{pH}$ (6.4) were similar and relatively uniform among the plots. The orchard had been planted in 1994 and trained to a modified vertical axe form with pollenizer crabapple trees located throughout. Drip (1994-2005) and low-flow microsprinkler (2006-2007) irrigation systems were used to supplement precipitation at the site during drought periods. The irrigation system was altered in 2006 raising the emitters to $0.5 \mathrm{~m}$ above ground, improving access for the cultivation equipment.

A windbreak of European black alder [Alnus glutinosa (L.) Gaertn.] bordered the north and east sides of the experiment, beyond which were Cornell University landscape plantings that included unsprayed ornamental crabapples (Malus spp.). A conventionally managed block of 'Fortune' apple trees bordered the experiment to the south with the next block of apple trees $25 \mathrm{~m}$ farther south. The next closest planting of conventionally managed orchard was $80 \mathrm{~m}$ to the west. Prevailing winds at the site were from the northwest. Although the orchard was in close proximity to conventionally managed orchards, the site provided ample influx of pests and diseases from surrounding flora and would be similar to commercial plantings in the region. For the 10 years before the implementation of this project, the orchard was under an insect and disease management program typical of commercial New York orchards as described in Agnello (2007). Predatory mites were well established at the site, and no residual soil-active herbicides had been used in the 6 years before this experiment began.

A randomized complete block design with four replications of the two production systems (IFP and OFP) was implemented in 2004 (Peck et al., 2009). Each experimental plot consisted of four adjacent rows, each containing 16 trees. The experimental design and execution of the treatments were intended to prevent spray drift among plots. All sampling occurred in the center 12 trees of the two middle rows of each experimental plot with buffer trees on all sides. Chemical thinners, crop protectants, and foliar fertilizers were applied on a tree row volume basis of $935 \mathrm{~L} \cdot \mathrm{ha}^{-1}$ with a compact Turbo-mist curtain airfoil sprayer (Slimline Manufacturing Ltd., Penticton, British Columbia, Canada). An unsprayed buffer row of trees was situated between the northern and southern treatment blocks and between the southern block and the 'Fortune' apple trees to the south. Sprays were directed toward the sample area within the exterior nonsample rows. Close inspection of the orchard after applications of the highly visible kaolin clay during each growing season confirmed that spray cross-contamination across plots was negligible.

An intensive IPM program was used to make pest control decisions in both treat- ments. Before bloom, pheromone lure traps for codling moth [Cydia pomonella (L.)], oriental fruit moth [Grapholita molesta (Busck)] and lesser appleworm [Grapholita prunivora (Walsh)], spotted tentiform leafminer [Phyllonorycter blancardella (Fabr.)], obliquebanded leafroller [Choristoneura rosaceana (Harris)], and white sticky traps for tarnished plant bug [Lygus lineolaris (Palisot de Beauvois)], and European apple sawfly [Hoplocampa testudinea (Klug)] were placed in each of the eight plots to monitor weekly pest flights. Sampling for folivorous and beneficial arthropods was also conducted weekly throughout the growing season, as described in Agnello (2007). Insecticide applications were timed based on these monitoring data, species- and site-specific degreeday-based phenological models, and local knowledge of the pest complex. If more than one pesticide was permitted to control a particular pest within a treatment, then the preferable material was selected based on toxicity, efficacy, residual activity, cost, and recommendations from Cornell Cooperative Extension personnel and farm management.

In addition to the sprayed chemicals, various cultural practices were used following recommended ecological pest control approaches under both IFP and organic certification schemes (Carroll and Robinson, 2006; Federal Register, 2000). Pheromone mating disruption (PMD) was used throughout the planting for codling moth and oriental fruit moth in 2006 (Isomate ${ }^{\circledR} \mathrm{C}$ Plus at 988 ties/ha and Isomate-M-100 at 371 ties/ha) and 2007 (Isomate ${ }^{\circledR} \mathrm{CM} / \mathrm{OFM}$ TT at 484 ties/ha). To trap out apple maggot flies, red spherical sticky traps with an apple fruit essence (butyl hexanoate ester) attractant volatile were placed in early July around the perimeter of the entire experimental orchard at a distance of $10 \mathrm{~m}$ between traps with fruit removed within a $30-\mathrm{cm}$ radius of each trap (Prokopy et al., 2003; Rull and Prokopy, 2004). Whenever the same a.i. was applied to both systems, equivalent rates were used. Other orchard operations such as pruning, irrigation, and mowing were the same in both treatments.

Neither IFP nor OFP systems have been widely used for apples in New York, so available guidelines and personal knowledge of how the systems operate in other applegrowing regions were used in conjunction with consultations with practicing growers and Cornell Cooperative Extension personnel to develop the management strategies for each system. During all 4 years, the overall treatments (IFP or OFP) were maintained. However, as a result of variable weather, changing pest and disease complexes, the availability of new products, and results from the previous seasons, the inputs and cultural practices were adapted somewhat to the specific seasonal conditions each year, like in comparable commercial operations. A list of all pesticide and foliar fertilizer materials, rates, and application dates used for both systems can be found in Peck (2009).

Integrated fruit production-certifiable treatment. The IFP system followed published 
New York IFP standards (Carroll and Robinson, 2006). Broad-spectrum pesticides (i.e., organophosphates, carbamates, chlorinated hydrocarbons, synthetic pyrethroids, and residual soil-active herbicides) that are often used in conventional apple orchards in New York were not applied in the IFP treatment. Instead, IFP used Environmental Protection Agency-defined "reduced risk" pesticides, which have "low impact on human health, low toxicity to non-target organisms (birds, fish, and plants), low potential for groundwater contamination, lower use rates, low pest resistance potential, and compatibility with Integrated Pest Management" (http://www.epa.gov/opprd001/workplan/ reducedrisk.html). Products included indoxacarb $\left(\right.$ Avaunt $\left.^{\circledR}\right)$, spinosad $\left(\right.$ SpinTor $\left.^{\circledR}\right)$, several neonicotinoids [acetamiprid (Assail ${ }^{\circledR}$ 70WP), thiacloprid $\left(\right.$ Calypso $\left.^{\circledR}\right)$, and thiamethoxam $\left(\right.$ Actara $\left.^{\mathrm{TM}}\right)$ ], and bifenazate (Acramite ${ }^{\circledR}$ ) and were applied at labeled rates. Two "attract and kill" (pheromones mixed with a synthetic pyrethroid in a sticky carrier) products (LastCall $^{\text {TM }}$ CM and LastCall ${ }^{T M}$ OFM) were applied to the IFP orchard at a rate of two drops per tree in 2004. Streptomycin was applied when fire-blight infections were likely based on the CougarBlight model (Smith, 1999). When predictive models and scouting records indicated high risk of infections by Botryosphaeria rot (Botryosphaeria dothidea), sooty blotch (SB) [a fungal complex including Peltaster fruticola (Johnson, Sutton \& Hodges), Leptodontium elatius (G. Mangenot) De Hoog, and Geastrumia polystigmatis Batista \& M.L. Farr], and flyspeck (FS) [Schizothyrium pomi (Mont. \& Fr.) Arx], we applied stobilurin, kresoxim-methyl (Sov$\operatorname{ran}^{\circledR} ; 0.06 \mathrm{~kg}$ a.i./ha) or the strobilurinanilide mixture of pyraclostrobin + boscalid (Pristine $^{\circledR} ; 0.13 \mathrm{~kg}$ a.i./ha $+0.26 \mathrm{~kg}$ a.i./ha, respectively) (Brown and Sutton, 1995). To control weeds in the IFP system, two glyphosate herbicide treatments $(2.9 \mathrm{~kg}$ a.i./ha $)$ were applied in 2004 and 2005, none in 2006, and one in 2007. To minimize herbicide applications while improving soil quality (Yao et al., 2005), a 1-m-wide composted hardwood bark chip mulch (obtained from local sawmills) was placed under the IFP trees to an average depth of $7.6 \mathrm{~cm}$ using a sidedischarge Millcreek ${ }^{\mathrm{TM}}$ Row Mulcher (Leola, PA) in Nov. 2005. Chemical fruit thinning occurred at petal fall and at 10- to $12-\mathrm{mm}$ fruitlet diameter with naphthaleneacetic acid (Fruitone $\mathrm{N}^{\circledR} ; 0.0074 \mathrm{~kg}$ a.i./ha) or 6-benzyladenine (Exilis ${ }^{\circledR}$ Plus; 0.07 to $0.093 \mathrm{~kg}$ a.i./ha) in conjunction with carbaryl $(0.52 \mathrm{~kg}$ a.i./ha) followed by selective hand-thinning in mid-June each year. Foliar nutrients consisted of average yearly (2005-2007) spring to early summer applications of Solubor ${ }^{\circledR}$ DF (US Borax Inc., Valencia, CA; $\left.1.8 \mathrm{~kg} \cdot \mathrm{ha}^{-1}\right)$, zinc EDTA (3.8 L $\left.\cdot \mathrm{ha}^{-1}\right)$, Epsom salt $\left(28 \mathrm{~kg} \cdot \mathrm{ha}^{-1}\right)$, and urea (2.8 kg.ha- ${ }^{-1}$ in 2006-2007 only). Calcium chloride was applied in late summer at a yearly (2005-2007) average of 10.2 $\mathrm{kg} \cdot \mathrm{ha}^{-1}$. In Fall 2005-2007, sulfate of potashmagnesia (Sul-Po-Mag) was applied at a rate of $112 \mathrm{~kg} \mathrm{~K} 2 \mathrm{O} / \mathrm{ha}$.
Organic fruit production-compliant treatment. The organic treatment followed USDA-NOP rules and the published list of approved materials (Federal Register, 2000; http://www.omri.org). The last nonorganically approved material was applied to the orchard on 18 Aug. 2003. Although the orchard was not eligible for organic certification as a result of the replicated design, on 19 Aug. 2006, the 36-month required transition period was completed. Bacillus thuringiensis $(B t), \mathrm{CpGV}\left(\mathrm{CYD}-\mathrm{X}^{\circledR}\right)$, petroleum oils, pyrethrum (PyGanic ${ }^{\circledR}$ EC 1.4 ${ }_{\text {II }}$ ), and spinosad $\left(\right.$ Entrust $\left.^{\circledR}\right)$ were used as insecticides at labeled rates. Kaolin clay particle film (Surround $^{\circledR}$ WP) was used as a crop protectant. Streptomycin for fire blight and lime sulfur and potassium carbonate for botryosphaeria rot and the SB/FS complex were applied based on the same decision protocol described for IFP. Organic weed control originally consisted of mechanical tillage with a tractormounted Rinieri side-sweep subsurface cultivator (Forli, IT) in 2004 (two passes) and 2005 (one pass) and subsequently consisted of a tractor-mounted Wonder Weeder (Harris Manufacturing, Burbank, WA) cultivator in 2005 (one pass), 2006 (three passes), and 2007 (three passes). Chemical fruit thinning in OFP involved applications of Crocker's fish oil (Quincy, WA) (18.3 kg a.i./ha) and liquid lime sulfur (4.1 to $8.1 \mathrm{~kg}$ a.i./ha) at petal fall and then again in 5 to $12 \mathrm{~d}$ followed by selective hand-thinning in mid-June each year. Foliar nutrients consisted of average yearly (2005-2007) spring to early summer applications of Solubor ${ }^{\circledR}$ DF $\left(1.8 \mathrm{~kg} \cdot \mathrm{ha}^{-1}\right)$, Yeoman ${ }^{\circledR}$ brand $7 \%$ zinc (Northwest Agricultural Products, Pasco, WA; $4.8 \mathrm{~L} \cdot \mathrm{ha}^{-1}$ ), Epsom salt $\left(28 \mathrm{~kg} \cdot \mathrm{ha}^{-1}\right)$, and Mermaid ${ }^{\text {TM }}$ Soluble Fish Powder (IFM, Wenatchee, WA; 11\% N; 12 $\mathrm{kg} \cdot \mathrm{ha}^{-1}$ ). Natural-Cal (Genesis AgriProducts, Yakima, WA) was applied in late summer at a yearly (2005-2007) average of $75.2 \mathrm{~L} \cdot \mathrm{ha}^{-1}$. To supplement tree nutrition and soil organic matter, chicken manure compost (in pellet form) was applied beneath the trees at a rate of $697 \mathrm{~kg}$ (fresh wt)/ha (equivalent to $78 \mathrm{~kg}$ $\mathrm{N} / \mathrm{ha}$ ) in Oct. 2005. In Fall 2005-2007, sulfate of potash-magnesia (K-Mag) was applied at a rate of $112 \mathrm{~kg} \mathrm{~K} \mathrm{O}_{2} \mathrm{O}$ ha.

Orchard productivity. Fruit were harvested on one harvest date in 2004, two sequential harvests in 2005, and three harvests in 2006 and 2007. The sequential harvests were used to assess fruit maturity (Peck et al., 2009). Trees next to pollenizers or gaps were avoided for harvest assessments. Annual tree growth was measured by calculating trunk cross-sectional area (TCSA) from measurements of trunk circumference at $20 \mathrm{~cm}$ above the graft union on all 'Liberty' trees within the sample area. Calculations of harvested yield, number, and weight of fruit that dropped to the ground before harvest, yield including dropped fruit, yield efficiency (yield including dropped fruit per TCSA), crop load (number of fruit including dropped fruit per TCSA), and average fruit weight were calculated by counting and weighing all of the fruit from at least three randomly selected sample trees per plot per harvest date.

Leaf nutrient concentrations. In early August of each year, a pooled sample of 100 midterminal shoot leaves in each plot was taken from midcanopy height. Leaves were dried at $82^{\circ} \mathrm{C}$ to constant weight and analyzed for total carbon $(\mathrm{C})$ and total nitrogen $(\mathrm{N})$ by Dumas combustion and for essential macroand micronutrients with an inductively coupled argon plasma (ICP) spectrophotometer at the Cornell Nutrient Analysis Laboratory on a dry weight basis (Kalra, 1998).

Cullage assessment. All apples from one harvest date in each year (mean of 815 fruit per block) were graded on a computer automated MAF-RODA Pomone fruit sorter (Montauban Cedex, France) for fruit weight and USDA-defined color grade (Federal Register, 2002). Box-size packouts (19.1-kg equivalent) were determined by fruit count based on fruit size. For example, an 80-count box consisted of 80 apples, each weighing between 203 to $255 \mathrm{~g}$. These fruit were also visually inspected, and arthropod, disease, and cosmetic damage were tallied. Where applicable, USDA grading definitions for injury and damage were used (Federal Register, 2002).

Environmental Impact Quotient. The Environmental Impact Quotient (EIQ) generates composite values for each pesticide based on calculated rankings for dermal toxicity, chronic toxicity, systemicity, fish toxicity, leaching potential, surface loss potential, bird toxicity, soil half-life, honeybee toxicity, beneficial arthropod toxicity, and pesticide half-life on the plant surface (Kovach et al., 1992). The EIQ values for this study were based on the most recently updated version (Mar. 2009) of the online database (http:// nysipm.cornell.edu/publications/eiq/default. asp). The value for sulfur was used for liquid lime sulfur, the value for petroleum oil was used for fish oil, and the value for pyrethrin was used for pyrethrum (J. Kovach, personal communication). Values for naphthaleneacetic acid, 6-benzyladenine, and $\mathrm{CpGV}$ were not available for the EIQ model, but these materials were applied in very small quantities and would not likely have contributed significantly to the EIQ values. Field use ratings were calculated by multiplying the EIQ value by the percent a.i. and then by the application rate (Kovach et al., 1992). Field use EIQ for all materials used each year were summed and reported as EIQ ha/year.

Variable costs of production. Partial budgets for the costs of production (machinery, labor, and materials) were compiled for each system, taking into account the variable costs of machinery use, materials, and labor for operations that were different between systems. For example, this assessment did not include mowing or pruning because these operations were the same in both systems. Equipment costs and wages were based on a 20-ha farm using New York State data from White (2008) and White et al. (2008). Fixed costs were assumed to be equal between the systems and were not included in the 
analysis. It was assumed that the farm already owned all necessary machinery except the Millcreek mulcher and the Wonder Weeder. For all other equipment, only variable operation costs (fuel, repairs, and lubrication) were calculated. Monetary values are reported in U.S. dollars. For the Millcreek mulcher, a rental rate of $\$ 150 / \mathrm{d}$ and an application rate of $2 \mathrm{ha} \cdot \mathrm{d}^{-1}$ were estimated. The fixed cost for the Wonder Weeder was calculated at \$575/year and included salvage value, interest, and interest on salvage value (assuming that the implement was purchased for $\$ 5000$ and would last for 10 years). The operating cost of the Wonder Weeder (not including the tractor) was calculated at $\$ 1.50 / \mathrm{h}$ (based on $60 \%$ of total repair costs over $2000 \mathrm{~h}$ of life). The Wonder Weeder costs were used for all 4 years of budget estimates in this experiment and excluded the costs of owning and operating the Rinieri cultivator. A diesel fuel rate of $\$ 0.88 / \mathrm{L}$ was used for all 4 years of this study. The following machinery rates were used: spray tractor (62-HP, 2WD, spray cab) at $\$ 12.92 / \mathrm{h}$; tractor (45-HP, 4WD) for cultivation, herbicide application, and spreading compost and bark mulch at $\$ 11.87$ / $\mathrm{h}$; air-blast sprayer (1136 L) at $\$ 3.90 / \mathrm{h}$; and herbicide sprayer (189 L) at $\$ 0.41 / \mathrm{h}$.

For skilled labor (tractor spraying), the rate was $\$ 18.55 / \mathrm{h}$; for semiskilled labor (tractor driving while applying bark mulch and compost and when cultivating), the rate was $\$ 14.39 / \mathrm{h}$; and for unskilled labor (spreading bark mulch and compost, hand-hoeing, hand-thinning, and hanging the pheromone mating disruption dispensers), the rate was $\$ 11.17 / \mathrm{h}$ (White, 2008). For harvesting, the rate was $\$ 0.07 / \mathrm{kg}$, which included seasonal labor, tractor drivers, and truck drivers. The same hourly rates were used for all 4 years of this experiment.

Potential market value of fruit. Potential prices received for marketable fruit were estimated for two venues: a direct market operation such as a retail farm stand or farmers' market that made and sold cider onsite as a value-added product and a wholesale market where the selling price represented the money going to the packinghouse or broker. Neither direct market nor wholesale prices represented net returns to the grower in our survey. Costs such as overhead, employee wages, and marketing and storage fees were not subtracted from reported values. The main economic objective was to assess potential differences in returns between each production system in the two markets.

The following assumptions were included in the price estimations in our analyses. First, the amount of fruit damage graded for either direct market or wholesale levels was subtracted from the total yields, assuming that the damage observed on sampled fruit was similar across all harvests within each year. Second, direct market prices were estimated from the Cornell Orchards commercial retail salesroom (where the fruit was ultimately sold), from two local apple growers, and from an informal survey of local supermarkets and natural foods stores. Third, because 'Liberty' has not been produced in enough volume to determine prevailing wholesale prices, wholesale prices were estimated from published prices for 'Empire' apples grown in the Hudson River Valley and sold from October through December (the timeframe that 'Liberty' is commonly marketed) at the New York City Terminal Produce Co-operative Market in Hunts Point (USDA AMS, 2008). 'Empire' apples are comparable to 'Liberty' in size, color, flavor profile, and harvest timing.

At the direct market level, all fruit weighing less than $122 \mathrm{~g}$ was assumed sold for cider at $\$ 0.59 / \mathrm{kg}$; fruit greater than $122 \mathrm{~g}$ was assumed sold for fresh eating at $\$ 1.84 / \mathrm{kg}$. The cider price was the estimated return per kilogram of fruit (not the higher potential return per liter of cider). Fruit that was superficially blemished but not internally damaged was valued at $\$ 1.84 / \mathrm{kg}$ as "orchard run," which assumed a higher consumer tolerance threshold for cosmetically imperfect fruit in the direct market.

At the wholesale market, fruit weighing less than $122 \mathrm{~g}$ was assumed sold for processing at $\$ 0.11 / \mathrm{kg}$; fruit between 122 and $141 \mathrm{~g}$ was valued at $\$ 0.52$ to $0.63 / \mathrm{kg}$; fruit between 140 and $167 \mathrm{~g}$ was valued at $\$ 0.63$ to $0.84 / \mathrm{kg}$; fruit between 166 and $204 \mathrm{~g}$ was valued at $\$ 0.63$ to $1.10 / \mathrm{kg}$; and fruit between 203 and $255 \mathrm{~g}$ was valued at $\$ 0.73$ to $1.36 / \mathrm{kg}$. These ranges represented year-to-year variations in average market value and differential prices based on established color grades (higher prices for greater percentage of red coloration). Fruit that was blemished but not internally damaged was graded for processing at $\$ 0.11 / \mathrm{kg}$.

Because the volume of East Coast organic apples sold through major produce terminals was not recorded by the USDA during this study, an average organic price differential of
$56 \%$ was estimated based on average organic and conventional sales data for eight apple cultivars (without regard to origin, color grade, size, or month of sale) sold in the Boston produce terminal during 2006 and 2007 (USDA ERS, 2008). Fruit from the 2006 and 2007 OFP harvests were considered as organic and received the price premium.

Statistical analyses. Statistical analyses included the years and treatments in a mixed model to assess the long-term effects of each production system using the PROC MIXED procedure of SAS 9.1 (Cary, NC). The mixed model included year (2004-2007), Treatment (IFP and OFP), and their interactions as fixed effects. Block and treatment $\times$ block were random effects. Main effects (year, treatment), interactions (year $\times$ treatment), and treatment effects within an interaction were considered significant at the $P=0.05$ level. For yield data - including crop density, yield efficiency, and fruit size data - the sequential harvest timings within years were not included in the model. An arcsin-square root transformation was performed before the analyses for fruit damage, but data are presented here as untransformed means.

\section{Results}

Orchard productivity. Cumulative yields (2004-2007) of harvested and total (harvested + dropped) fruit were similar between treatments, except in 2007 when IFP total yields were $18 \%$ greater than OFP yields (Fig. 1). Over the 4 years, tree size (TCSA) remained similar between production systems (Table 1). In the IFP system, there were greater crop densities in 2007 and greater yield efficiencies in 2006 and 2007. Average weight (a measure of fruit size) of apples grown under

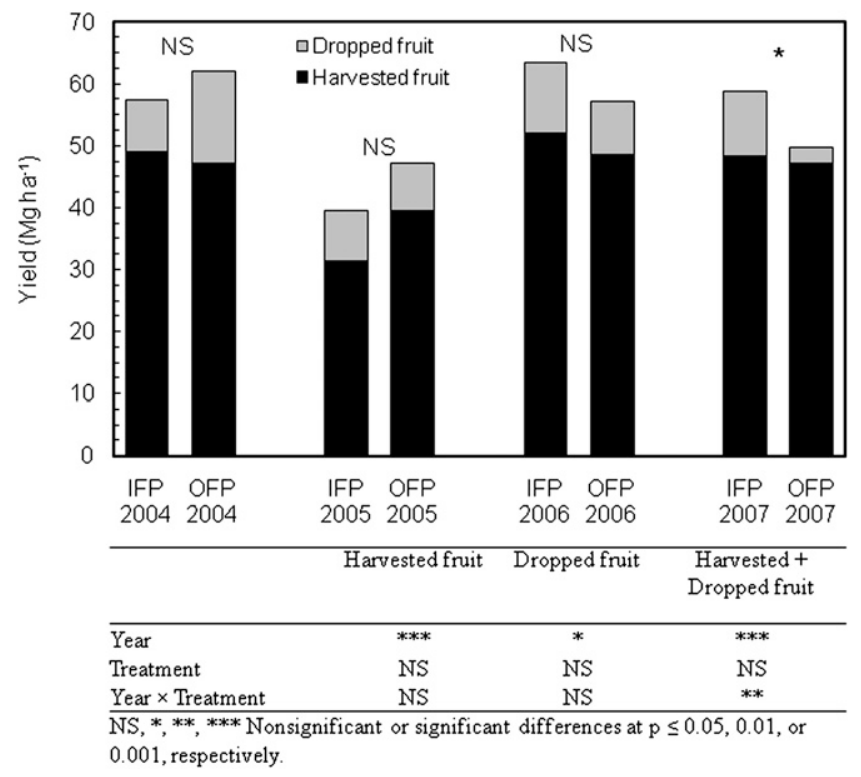

Fig. 1. Apple yields under integrated (IFP) and organic fruit production (OFP) systems during 4 years. Significance levels of main effects (year or treatment) and interactions are at the bottom of the figure. Significance symbols $(*)$ are for treatment effects within the year $\times$ treatment interaction for the harvested + dropped fruit yield. Values represent one harvest date in 2004, two in 2005, and three in both 2006 and 2007. At least three entire trees per plot were harvested per harvest date. 
OFP was lower than apples grown under IFP in 2005. In 2006, the OFP-grown apples were smaller than those in the other 3 years. IFP fruit weight decreased in 2006 and 2007 compared with the two preceding years. Overall, average fruit weight was not closely correlated with yield, indicating that larger fruit were not always produced in the years and treatments with lower yields.

Leaf nutrient concentrations. More C, but not more $\mathrm{N}$ nor a greater ratio of $\mathrm{C}: \mathrm{N}$, was found in the IFP leaves (Table 2). Leaf $\mathrm{N}$ content was at or below the lower suggested nutrient range for IFP trees from 2005 to 2007 and for OFP trees in 2005 and 2007. Leaf phosphorous $(\mathrm{P})$ concentrations were not different between systems and remained within appropriate ranges during all 4 years. Leaf potassium $(\mathrm{K})$ concentrations were higher in OFP trees than in IFP trees throughout the experiment. Leaf $\mathrm{N}$ concentrations for both systems declined after the first year, but $\mathrm{P}, \mathrm{K}$, and calcium $(\mathrm{Ca})$ increased after the bark mulch (IFP) and compost (OFP) additions occurred postharvest in 2005. In both systems, leaf $\mathrm{K}, \mathrm{Ca}$, magnesium $(\mathrm{Mg})$, manganese $(\mathrm{Mn})$, iron $(\mathrm{Fe})$, copper $(\mathrm{Cu})$, boron (B), and zinc $(\mathrm{Zn})$ concentrations were below recommended nutrient ranges in at least 1 year. When treatment differences in leaf nutrient differences were detected, the IFP trees tended to have lower nutrient values than OFP trees. One conspicuous difference in leaf nutrient levels was the eight- to 14fold greater concentration of aluminum (Al) in the leaves of OFP trees.

Cullage assessment. Apples from one harvest date in each year were assessed for

Table 1. Trunk cross-sectional areas (TCSA; estimated from trunk circumferences measured $20 \mathrm{~cm}$ above the graft union), crop density, yield efficiency, and average fruit weight for apples under integrated (IFP) and organic fruit production (OFP). ${ }^{\mathrm{z}}$

\begin{tabular}{|c|c|c|c|c|c|}
\hline Year & Treatment & $\begin{array}{l}\text { TCSA } \\
\left(\mathrm{cm}^{2}\right)\end{array}$ & $\begin{array}{c}\text { Crop density } \\
\text { (no. of fruit } \mathrm{TCSA}^{-1} \text { ) }\end{array}$ & $\begin{array}{c}\text { Yield efficiency } \\
\text { (no. of fruit } \mathrm{TCSA}^{-1} \text { ) }\end{array}$ & $\begin{array}{l}\text { Avg fruit wt } \\
(\mathrm{g})\end{array}$ \\
\hline 2004 & IFP & 47 & 4.9 & 0.80 & 165 \\
\hline 2004 & OFP & 51 & 5.4 & 0.80 & 148 \\
\hline 2005 & IFP & 51 & 3.4 & 0.56 & 167 \\
\hline 2005 & OFP & 53 & 4.1 & 0.60 & 145 \\
\hline 2006 & IFP & 55 & 5.9 & 0.81 & 139 \\
\hline 2006 & OFP & 58 & 5.1 & 0.63 & 126 \\
\hline 2007 & IFP & 56 & 5.8 & 0.74 & 129 \\
\hline 2007 & OFP & 59 & 3.9 & 0.55 & 142 \\
\hline Year & & $* * *$ & $* * *$ & $* * *$ & $* * *$ \\
\hline \multicolumn{2}{|c|}{ Treatment } & NS & NS & * & NS \\
\hline \multicolumn{2}{|c|}{ Year $\times$ treatment } & NS & $* * *$ & $*$ & $* * *$ \\
\hline
\end{tabular}

Treatment effects within the year $\times$ treatment interaction

\begin{tabular}{|c|c|c|c|}
\hline 2004 & NS & NS & NS \\
\hline 2005 & NS & NS & $*$ \\
\hline 2006 & NS & $* *$ & NS \\
\hline 2007 & $* * *$ & $* * *$ & NS \\
\hline
\end{tabular}

${ }^{\mathrm{z}}$ Significance levels of main effects (year or treatment), interactions, and treatment effects within interactions are at the bottom of the table. Values represent one harvest date in 2004, two in 2005, and three in both 2006 and 2007. At least three entire trees per plot were harvested per harvest date. NS, $* * *, * * *$ Nonsignificant or significant differences at $P \leq 0.05,0.01$, or 0.001 , respectively. various cullage defects (Table 3 ). Internal Lepidoptera (i.e., codling moth, oriental fruit moth, and lesser apple worm) damage was nearly 16 -fold greater in OFP-grown fruit in 2005 and six times greater in 2007 compared with IFP. Fruit damage from internal Lepidoptera was well above New York State averages for commercial orchards (less than $5 \%$, codling moth; less than $1 \%$ lesser apple worm; less than $10 \%$ oriental fruit moth) in the OFP system during 2005 but not as severe as in unmanaged New York orchards, which can sustain $30 \%$ to $40 \%$ Lepidoptera fruit damage (Harrington and Good, 2000). Similarly, throughout this experiment, there was more plum curculio [Conotrachelus nenuphar (Herbst)] damage to fruit in the OFP system, although the amount of damage remained within state averages for commercial orchards (less than 5\%) and well below amounts reported in unsprayed orchards $(60 \%)$ (Harrington and Good, 2000). European apple sawflies, plant bugs (Lygus spp.), and other arthropods including Leafrollers (Tortricidae), pentatomids, green fruitworms [several species causing similar damage such as Orthosia hibisci (Guenée), Lithophane antennata (Walker), and Amphipyra pyramidoides (Guenée)] and woolly apple aphids [Eriosoma lanigerum (Hausmann)] \} caused varying degrees of damage to harvested fruit. During this study, no apple maggot damage was observed in fruit from either system. Aggregate damage from all arthropod pests ranged from $3 \%$ to $6 \%$ and did not vary much in IFP-grown fruit, whereas aggregate arthropod pest damage in OFP-grown fruit was $3 \%$ in 2004, increased to $25 \%$ in 2005 , and then decreased to $14 \%$ in the final 2 years. Aggregate damage from all arthropod pests was significantly greater in the OFP system than the IFP system in all but the first year of this experiment.

The summer SB/FS disease complex as well as russeting and scarfskin was more severe for the OFP system in the final 2

Table 2. Leaf nutrient concentrations from trees under integrated (IFP) and organic fruit production (OFP) systems during 4 years. ${ }^{z}$

\begin{tabular}{|c|c|c|c|c|c|c|c|c|c|c|c|c|c|c|}
\hline Year & Treatment & $\begin{array}{c}\text { Carbon } \\
(\%)\end{array}$ & $\begin{array}{c}\text { Nitrogen } \\
(\%)\end{array}$ & $\begin{array}{l}\text { Carbon: } \\
\text { nitrogen }\end{array}$ & $\begin{array}{c}\text { Phosphorus } \\
(\%)\end{array}$ & $\begin{array}{c}\text { Potassium } \\
(\%)\end{array}$ & $\begin{array}{c}\text { Calcium } \\
(\%)\end{array}$ & $\begin{array}{c}\text { Magnesium } \\
(\%)\end{array}$ & $\begin{array}{c}\text { Manganese } \\
(\mathrm{ppm})\end{array}$ & $\begin{array}{c}\text { Iron } \\
(\mathrm{ppm})\end{array}$ & $\begin{array}{c}\text { Copper } \\
(\mathrm{ppm})\end{array}$ & $\begin{array}{l}\text { Boron } \\
\text { (ppm) }\end{array}$ & $\begin{array}{c}\text { Zinc } \\
(\mathrm{ppm})\end{array}$ & $\begin{array}{l}\text { Aluminum } \\
\text { (ppm) }\end{array}$ \\
\hline 2004 & IFP & 47.6 & 2.03 & 23.5 & 0.152 & 1.01 & 1.02 & 0.268 & 21.7 & 49.3 & 5.95 & 31.9 & 10.4 & 67.1 \\
\hline 2004 & OFP & 46.9 & 2.02 & 23.3 & 0.153 & 1.03 & 1.12 & 0.265 & 22.1 & 64.7 & 5.72 & 32.7 & 11.0 & 537 \\
\hline 2005 & IFP & 48.5 & 1.83 & 26.6 & 0.216 & 1.10 & 1.01 & 0.262 & 16.3 & 48.4 & 5.67 & 48.2 & 30.5 & 85.8 \\
\hline 2005 & OFP & 47.5 & 1.75 & 27.1 & 0.207 & 1.32 & 1.17 & 0.273 & 20.8 & 66.3 & 6.35 & 42.5 & 22.5 & 702 \\
\hline 2006 & IFP & 47.2 & 1.75 & 27.1 & 0.206 & 1.33 & 1.19 & 0.268 & 26.8 & 60.2 & 7.90 & 35.1 & 19.3 & 39.6 \\
\hline 2006 & OFP & 46.4 & 1.94 & 24.0 & 0.182 & 1.52 & 1.63 & 0.296 & 25.1 & 69.2 & 9.22 & 37.2 & 35.1 & 439 \\
\hline 2007 & IFP & 46.1 & 1.78 & 26.4 & 0.243 & 1.23 & 1.25 & 0.281 & 19.7 & 48.3 & 6.41 & 28.9 & 27.3 & 37.8 \\
\hline 2007 & OFP & 45.6 & 1.80 & 25.4 & 0.235 & 1.39 & 1.38 & 0.294 & 18.9 & 66.7 & 7.52 & 26.7 & 34.7 & 509 \\
\hline \multicolumn{2}{|c|}{ Suggested nutrient ranges ${ }^{y}$} & & $1.8-2.2$ & & $0.13-0.33$ & $1.35-1.85$ & $1.3-2.0$ & $0.35-0.5$ & $50-150$ & $50+$ & $7.0-12$ & $35-50$ & $35-50$ & $\mathrm{~N} / \mathrm{A}^{\mathrm{x}}$ \\
\hline \multirow{3}{*}{\multicolumn{2}{|c|}{$\begin{array}{l}\text { Year } \\
\text { Treatment } \\
\text { Year } \times \text { treatment }\end{array}$}} & $* * *$ & $* *$ & $* *$ & $* * *$ & $* * *$ & $* * *$ & $* * *$ & $* * *$ & NS & $* * *$ & $* * *$ & $* * *$ & $* * *$ \\
\hline & & $* * *$ & NS & NS & NS & $* * *$ & $* * *$ & $* *$ & NS & $* * *$ & $* * *$ & NS & NS & $* * *$ \\
\hline & & NS & NS & NS & NS & NS & $* *$ & $*$ & $* *$ & NS & $* *$ & $*$ & $* * *$ & $*$ \\
\hline \multicolumn{15}{|c|}{ Treatment effects within the year $\times$ treatment interaction } \\
\hline \multicolumn{7}{|l|}{2004} & NS & NS & NS & & NS & NS & NS & $* * *$ \\
\hline \multicolumn{7}{|l|}{2005} & $*$ & NS & $* * *$ & & $*$ & $* *$ & $* *$ & $* * *$ \\
\hline \multicolumn{7}{|l|}{2006} & $* * *$ & $* * *$ & NS & & $* * *$ & NS & $* * *$ & $* * *$ \\
\hline \multicolumn{2}{|l|}{2007} & & & & & & NS & NS & NS & & $* * *$ & NS & $* *$ & $* * *$ \\
\hline
\end{tabular}

${ }^{\mathrm{z}}$ Significance levels of main effects (year or treatment), interactions, and treatment effects within interactions are at the bottom of the table. Values represent pooled samples of 100 midterminal shoot leaves per plot taken from midcanopy height each August.

${ }^{\mathrm{y}}$ Stiles and Reid, 1991.

${ }^{\mathrm{x}}$ Not available.

Ns, *,**,***Nonsignificant or significant differences at $P \leq 0.05,0.01$, or 0.001 , respectively. 
Table 3. Percent of arthropod damage, diseases, and surface damage on fruit harvested at maturity under integrated (IFP) and organic fruit production (OFP) systems during 4 years. ${ }^{2}$

\begin{tabular}{|c|c|c|c|c|c|c|c|c|c|c|c|c|c|c|}
\hline Year & Treatment & $\begin{array}{c}\text { Internal } \\
\text { Lepidoptera } \\
\text { (fruit feeding) } \\
(\%)\end{array}$ & $\begin{array}{l}\text { Plum } \\
\text { curculio } \\
(\%)\end{array}$ & $\begin{array}{l}\text { European } \\
\text { apple } \\
\text { sawfly } \\
(\%)\end{array}$ & $\begin{array}{c}\text { Plant } \\
\text { bug } \\
(\%)\end{array}$ & $\begin{array}{c}\text { Other } \\
\text { arthropod } \\
\text { damage } \\
(\%)\end{array}$ & $\begin{array}{l}\text { Flyspeck/ } \\
\text { sooty } \\
\text { blotch } \\
(\%)\end{array}$ & $\begin{array}{c}\text { Russeting, } \\
\text { scarfskin, and } \\
\text { other markings } \\
(\%)\end{array}$ & $\begin{array}{l}\text { Misshaped } \\
\text { shaped } \\
(\%)\end{array}$ & $\begin{array}{l}\text { Other } \\
\text { fruit } \\
\text { defects } \\
(\%)\end{array}$ & $\begin{array}{l}\text { Aggregate } \\
\text { arthropod } \\
\text { damage } \\
(\%)\end{array}$ & $\begin{array}{l}\text { Aggregate } \\
\text { surface } \\
\text { damage } \\
(\%)\end{array}$ & $\begin{array}{c}\text { Fruit } \\
\text { unmarketable } \\
\text { for fresh } \\
\text { sales }(\%)\end{array}$ & $\begin{array}{c}\text { Clean } \\
\text { fruit } \\
(\%)\end{array}$ \\
\hline 2004 & IFP & 0.2 & 0.6 & 1.5 & 0.6 & 0.0 & - & - & - & 0.0 & 2.9 & 0.1 & 0.3 & 97 \\
\hline 2004 & OFP & 0.9 & 0.6 & 0.6 & 0.6 & 0.2 & - & - & - & 0.1 & 2.9 & 0.3 & 1.4 & 97 \\
\hline 2005 & IFP & 0.9 & 0.5 & 0.0 & 0.1 & 1.4 & 0.0 & 0.5 & 0.1 & 3.6 & 2.9 & 4.3 & 5.8 & 96 \\
\hline 2005 & OFP & 15 & 3.8 & 0.2 & 0.4 & 5.7 & 0.2 & 1.2 & 0.7 & 4.7 & 25 & 6.6 & 25 & 74 \\
\hline 2006 & IFP & 0.3 & 0.8 & 0.1 & 1.6 & 3.0 & 6.3 & 4.7 & 1.3 & 1.7 & 5.8 & 7.7 & 3.2 & 83 \\
\hline 2006 & OFP & 1.4 & 1.3 & 1.4 & 5.0 & 4.2 & 68 & 44.3 & 13 & 4.8 & 13 & 62 & 5.2 & 25 \\
\hline 2007 & IFP & 0.4 & 0.6 & 0.0 & 0.8 & 1.2 & 0.8 & 2.3 & 0.1 & 1.5 & 3.1 & 3.8 & 2.0 & 94 \\
\hline 2007 & OFP & 2.8 & 4.9 & 1.4 & 2.9 & 2.0 & 7.5 & 10.7 & 0.2 & 2.1 & 14 & 13 & 5.6 & 67 \\
\hline Year & & $* * *$ & NS & $* * *$ & $* * *$ & $* * *$ & $* * *$ & $* * *$ & $* * *$ & $* * *$ & $* * *$ & $* * *$ & $* * *$ & $* * *$ \\
\hline Treatn & nent & $* *$ & $*$ & $*$ & $* * *$ & $* *$ & $* * *$ & $* * *$ & $* * *$ & NS & $* * *$ & $* * *$ & $* *$ & $* * *$ \\
\hline Year $>$ & treatment & $* * *$ & NS & $* * *$ & $* *$ & $* *$ & $* * *$ & $* * *$ & $* * *$ & NS & $* * *$ & $* * *$ & $* * *$ & $* * *$ \\
\hline \multicolumn{15}{|c|}{ Treatment effects within the year $\times$ treatment interaction } \\
\hline 2004 & & NS & & $*$ & NS & NS & & & & & NS & NS & * & NS \\
\hline 2005 & & $* * *$ & & NS & $*$ & $* * *$ & NS & NS & NS & & $* * *$ & NS & $* *$ & $* * *$ \\
\hline 2006 & & NS & & $* * *$ & $* * *$ & NS & $* * *$ & $* * *$ & $* * *$ & & $* * *$ & $* * *$ & NS & $* * *$ \\
\hline 2007 & & $* *$ & & $* * *$ & $* * *$ & NS & $* * *$ & $* *$ & NS & & $* * *$ & $* * *$ & $*$ & $* * *$ \\
\hline
\end{tabular}

${ }^{\mathrm{z}}$ Significance levels of main effects (year or treatment), interactions, and treatment effects within interactions are at the bottom of the table. Data were arcsinsquare root transformed before analyses but presented as untransformed means representing the percentage of apples from one harvest date in each year that were visually identified for each damage.

NS, $* * *, * * *$ Nonsignificant or significant differences at $P \leq 0.05,0.01$, or 0.001 , respectively.

years of this project (Table 3). Little to no SB/FS was observed in 2004 or 2005 , but during 2006 (a very wet growing season), $6.3 \%$ of IFP-grown fruit and $68 \%$ of OFPgrown fruit showed SB/FS damage. In 2007 (a relatively warm and dry growing season), $1.5 \%$ of IFP-grown fruit and $10 \%$ of OFPgrown fruit showed $\mathrm{SB} / \mathrm{FS}$ symptoms. $\mathrm{Cu}-$ mulatively, OFP-grown apples had more surface defects than IFP-grown fruit in both 2006 and 2007. When the total number of fruit with at least one defect was calculated, IFP-grown fruit had from $83 \%$ to $97 \%$ unblemished fruit, whereas OFP-grown fruit had $25 \%$ to $97 \%$ unblemished fruit; the two systems differed from each other in 20052007. The damage recorded in OFP fruit during these final 3 years was greater than most conventionally managed New York apple orchards, which typically have $90 \%$ to $95 \%$ unblemished fruit (Agnello et al., 2005). These numbers represent the percent of unmarketable fruit for fresh market at the wholesale level. It was also apparent that for both of these systems, the amount of fruit cullage was lowest in the first year (2004) of this study.

Environmental Impact Quotient. The field use EIQ indicated 4.2 to 7.9 times more negative environmental impacts in the OFP system over the years (Fig. 2). For the IFP system, herbicides accounted for $11.5 \%$, fungicides accounted for $0.9 \%$, and insecticides accounted for $5.6 \%$ of the cumulative EIQ total. For the OFP system, fungicides accounted for $0.6 \%$ and insecticides accounted for $2.1 \%$ of the cumulative EIQ total. The largest EIQ contributors in OFP were kaolin clay (30\% to $78 \%$ of total EIQ per year) and the thinning spray combination of lime sulfur and oil (9\% to 53\% of total EIQ per year). Kaolin clay had the lowest possible EIQ value (8) but was applied in large quantities multiple times each season (174

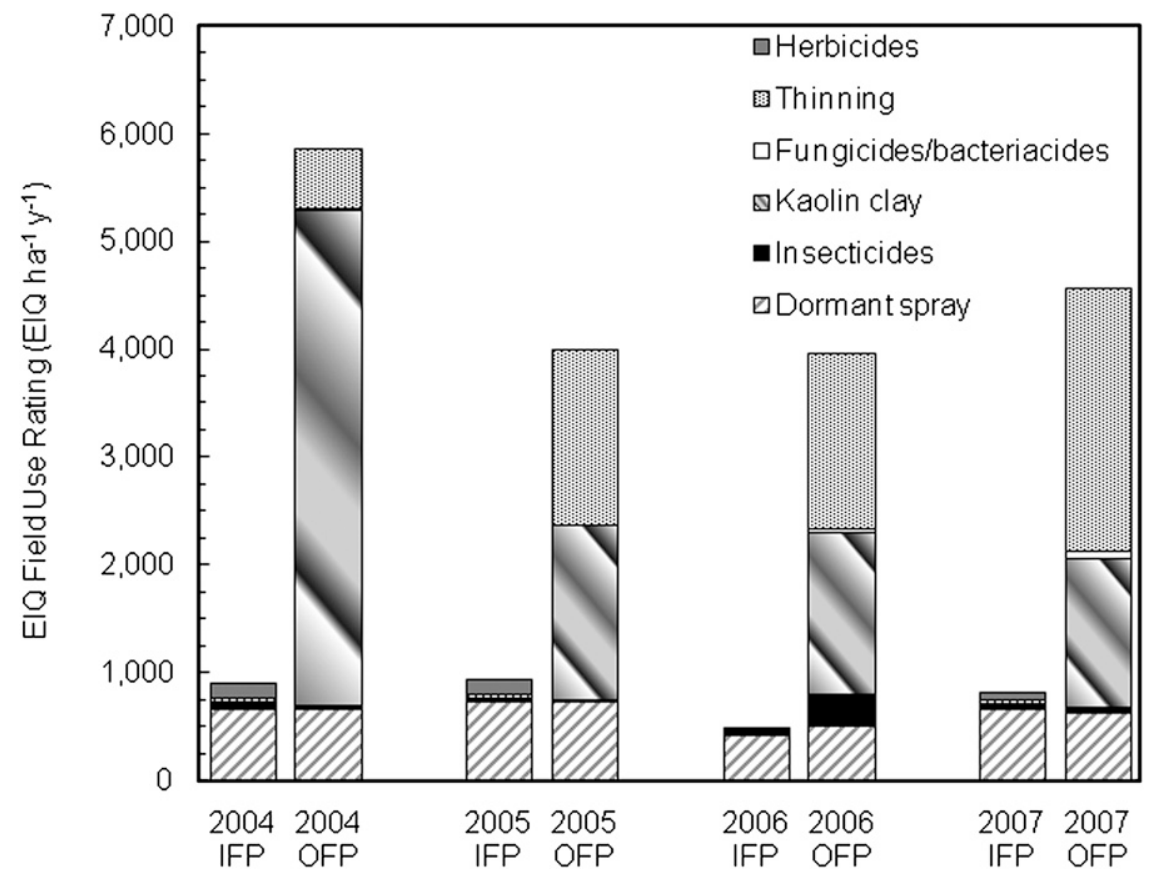

Fig. 2. Field use Environmental Impact Quotient (EIQ) rating for integrated (IFP) and organic fruit production (OFP) systems during 4 years. The field use rating equation multiplies the EIQ value $\times$ the percent a.i. $\times$ the rate per hectare for each material used. No statistical analysis was performed because all plots within a treatment received the same inputs.

to $575 \mathrm{~kg}$ a.i./ha/year), which greatly increased its field use EIQ rating. Lime sulfur and fish oil have high EIQ ratings (46 and 28 , respectively), and were used in relatively large quantities for fruit thinning in the OFP treatment. Stylet oil had the largest EIQ rating for a single application (250 EIQ units) when used as a miticide in 2006 for OFP. The dormant sprays of copper and oil had high but similar ratings for both systems.

Variable costs of production. When averaged over 4 years, the estimated variable costs that differed between systems were $9 \%(\$ 568 /$ ha $)$ greater per year under OFP compared with IFP (Table 4). In this study, the OFP system cost $19 \%$ more in machinery (\$51/ha), 19\% more in materials (\$313/ha), and 5\% more in labor (\$204/ha) than the IFP system when averaged over 4 years. Machinery costs were higher in the OFP because of the need to purchase a specialized cultivator (the Wonder Weeder), but its operating costs averaged only $\$ 28 /$ ha/year. More airblast sprays were needed in the OFP system, 


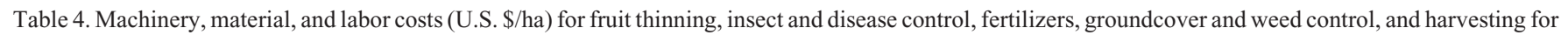
integrated (IFP) and organic fruit production (OFP) systems during 4 years. $^{\mathrm{z}}$

\begin{tabular}{|c|c|c|c|c|c|c|c|c|c|c|}
\hline & \multicolumn{2}{|c|}{2004} & \multicolumn{2}{|c|}{2005} & \multicolumn{2}{|c|}{2006} & \multicolumn{2}{|c|}{2007} & \multicolumn{2}{|c|}{ Grand mean } \\
\hline & IFP & OFP & IFP & OFP & IFP & OFP & IFP & OFP & IFP & OFP \\
\hline \multicolumn{11}{|l|}{ Machinery fixed costs } \\
\hline Wonder Weeder & 0 & 29 & 0 & 29 & 0 & 29 & 0 & 29 & 0 & 29 \\
\hline \multicolumn{11}{|l|}{ Machinery operating costs } \\
\hline Tractor + airblast sprayer & 270 & 312 & 187 & 208 & 208 & 229 & 166 & 229 & 208 & 244 \\
\hline Tractor + herbicide sprayer & 30 & 0 & 30 & 0 & 0 & 0 & 15 & 0 & 19 & 0 \\
\hline Tractor + Wonder Weeder & 0 & 22 & 0 & 22 & 0 & 33 & 0 & 33 & 0 & 28 \\
\hline Spreading chicken manure compost & 0 & 0 & 0 & 59 & 0 & 0 & 0 & 0 & 0 & 15 \\
\hline Mill Creek bark mulch spreading & 0 & 0 & 148 & 0 & 0 & 0 & 0 & 0 & 37 & 0 \\
\hline \multicolumn{11}{|l|}{ Material costs } \\
\hline Dormant spray & 37 & 47 & 39 & 39 & 28 & 123 & 37 & 109 & 35 & 79 \\
\hline Insecticides and miticides & 593 & 140 & 480 & 246 & 404 & 560 & 326 & 592 & 451 & 384 \\
\hline Kaolin clay & 0 & 1134 & 0 & 399 & 0 & 368 & 0 & 341 & 0 & 561 \\
\hline $\mathrm{PMD}^{\mathrm{y}}$ & 230 & 0 & 0 & 0 & 400 & 400 & 494 & 494 & 281 & 224 \\
\hline Fungicides & 64 & 22 & 0 & 0 & 112 & 69 & 69 & 17 & 61 & 27 \\
\hline Adjuvants & 5 & 11 & 0 & 0 & 0 & 32 & 8 & 22 & 3 & 16 \\
\hline Thinning & 35 & 154 & 313 & 297 & 131 & 297 & 127 & 446 & 152 & 299 \\
\hline Foliar fertilizers & 0 & 0 & 35 & 106 & 31 & 193 & 42 & 177 & 27 & 119 \\
\hline Herbicides & 105 & 0 & 105 & 0 & 0 & 0 & 38 & 0 & 62 & 0 \\
\hline Sul-Po-Mag/K-Mag & 129 & 232 & 129 & 232 & 129 & 232 & 129 & 232 & 129 & 232 \\
\hline Bark mulch & 0 & 0 & 1747 & 0 & 0 & 0 & 0 & 0 & 437 & 0 \\
\hline Chicken manure compost & 0 & 0 & 0 & 38 & 0 & 0 & 0 & 0 & 0 & 10 \\
\hline \multicolumn{11}{|l|}{ Labor costs } \\
\hline Tractor airblast spraying & 298 & 344 & 206 & 229 & 229 & 252 & 183 & 252 & 229 & 269 \\
\hline Herbicide application & 46 & 0 & 46 & 0 & 0 & 0 & 23 & 0 & 29 & 0 \\
\hline Bark mulch application & 0 & 0 & 340 & 0 & 0 & 0 & 0 & 0 & 85 & 0 \\
\hline Chicken manure application & 0 & 0 & 0 & 55 & 0 & 0 & 0 & 0 & 0 & 14 \\
\hline Cultivation & 0 & 28 & 0 & 28 & 0 & 42 & 0 & 42 & 0 & 35 \\
\hline Hand hoeing & 0 & 0 & 0 & 0 & 0 & 179 & 0 & 179 & 0 & 89 \\
\hline Hanging $\mathrm{PMD}^{\mathrm{y}}$ dispensers & 55 & 0 & 0 & 0 & 90 & 90 & 28 & 28 & 43 & 29 \\
\hline Hand thinning & 1021 & 1380 & 575 & 677 & 798 & 1028 & 852 & 687 & 812 & 943 \\
\hline Harvesting & 3256 & 3126 & 2085 & 2611 & 3450 & 3212 & 3199 & 3126 & 2997 & 3019 \\
\hline Total machinery costs & 301 & 362 & 366 & 317 & 208 & 290 & 181 & 290 & 264 & 315 \\
\hline Total material costs & 1197 & 1741 & 2848 & 1358 & 1235 & 2274 & 1270 & 2430 & 1637 & 1951 \\
\hline Total labor costs & 4676 & 4878 & 3252 & 3600 & 4567 & 4802 & 4285 & 4314 & 4195 & 4398 \\
\hline Grand total & $\$ 6174$ & $\$ 6981$ & $\$ 6465$ & $\$ 5275$ & $\$ 6010$ & $\$ 7366$ & $\$ 5736$ & $\$ 7034$ & $\$ 6096$ & $\$ 6664$ \\
\hline
\end{tabular}

${ }^{\mathrm{z}}$ No statistical analysis was performed because all plots within a treatment received the same inputs.

yPheromone mating disruption.

increasing its machinery and labor costs compared with IFP. Other machinery costs were nominal when averaged over the 4 years. Comparing the two systems, materials such as dormant sprays, foliar fertilizers, and Sul-Po-Mag/K-Mag were similar in dosage rates, but the organic formulations were generally more expensive per application. The costs of insecticides and miticides decreased in IFP and increased in OFP over the 4 years. The dosage and number of kaolin clay applications and the cost of this spray material decreased over the course of this experiment as we refined its use. Chemical thinning materials were approximately twice as expensive in OFP compared with IFP. Bark mulch was the most expensive material purchased in either treatment and accounted for $9 \%$ of the 4 -year total IFP costs. Harvesting accounted for $49 \%$ of the IFP labor costs and for $45 \%$ of OFP labor costs. Additional spraying, hand-hoeing, and hand-thinning were major contributors to the greater OFP labor costs.

Average annual costs for fruit thinning, arthropod and disease control, and fertilizers were $29 \%$ (\$278/ha), 40\% (\$522/ha), and $141 \%$ (\$219/ha) greater under OFP than IFP, respectively (Table 5). However, groundcover/ weed control costs were on average $73 \%$ (\$488/ha) greater in the IFP system. Greater OFP thinning costs were associated with OFP chemical thinning, which was more expensive and less effective than the IFP program, requiring more follow-up handthinning (Tables 4 and 5). For both systems, arthropod and disease control costs were lowest in 2005 when PMD was not used. In 2006 and 2007, when PMD was used in both systems, it accounted for 36\% of IFP and $24 \%$ of OFP arthropod and disease control costs. When PMD was not included, arthropod and disease costs in the IFP system were fairly constant over the 4 years of this study.

Potential market value of fruit. The first 36 months of this experiment would be considered the transition period for organic certification, and therefore after 18 Aug. 2006 , apples could have been sold as organic and eligible for the price premium that we estimated at 56\% (Table 6). Averaged over the 4 years, the sales value of OFP-grown apples was $6 \%$ greater than IFP-grown apples in the direct market, but IFP-grown apples had $11 \%$ greater sales value than OFP-grown apples in the wholesale market. In the direct market scenario, fresh sales accounted for $57 \%$ of IFP but only $36 \%$ of OFP total sales. The amount potentially received for blem- ished fruit in the wholesale market accounted for $1 \%$ to $9 \%$ of IFP and $1 \%$ to $67 \%$ of OFP sales each year. For both systems, under either marketing strategy, the greatest potential returns were seen in 2004 at the beginning of the transition period. In subsequent years, increased arthropod, disease, and cosmetic damage and decreased fruit size in both systems resulted in less fruit that could be marketed as "fresh" or "unblemished" compared with the first year (Tables 1 and 3). For both production systems, the percentage of fruit in the largest wholesale market size categories $(80,100$, and 120) diminished over 4 years (Table 6).

\section{Discussion}

Orchard productivity. Under both IFP and OFP systems, the disease-resistant cultivar Liberty maintained acceptable yields and tree growth. In all years of this study, yields for both treatments were comparable with yields recorded for this orchard during the 5 years before this experiment $\left(37 \mathrm{Mg} \cdot \mathrm{ha}^{-1}\right)$ and greater than average yields $\left(31 \mathrm{Mg} \cdot \mathrm{ha}^{-1}\right)$ reported for commercial apple orchards in New York (USDA NASS, 2008). However, these high yields resulted in part from inadequate chemical fruit thinning in both 
Table 5. Total machinery, material, and labor costs (U.S. \$/ha) for fruit thinning, arthropod and disease control, fertilizers, and groundcover/weed control for integrated (IFP) and organic fruit production (OFP) systems during 4 years. ${ }^{2}$

\begin{tabular}{|c|c|c|c|c|c|c|c|c|c|c|}
\hline & \multicolumn{2}{|c|}{2004} & \multicolumn{2}{|c|}{2005} & \multicolumn{2}{|c|}{2006} & \multicolumn{2}{|c|}{2007} & \multicolumn{2}{|c|}{ Grand mean } \\
\hline & IFP & $\overline{\mathrm{OFP}}$ & IFP & OFP & IFP & OFP & $\overline{I F P}$ & $\mathrm{OFP}$ & IFP & OFP \\
\hline Arthropod and disease control & 1552 & 2009 & 913 & 1122 & 1471 & 2122 & 1312 & 2083 & 1312 & 1834 \\
\hline
\end{tabular}

${ }^{2}$ No statistical analysis was performed because all plots within a treatment received the same inputs.

Table 6. Estimated direct and wholesale market sales values (U.S. \$/ha) for apples produced under integrated (IFP) and organic fruit production (OFP) systems during 4 years. ${ }^{\mathrm{z}}$

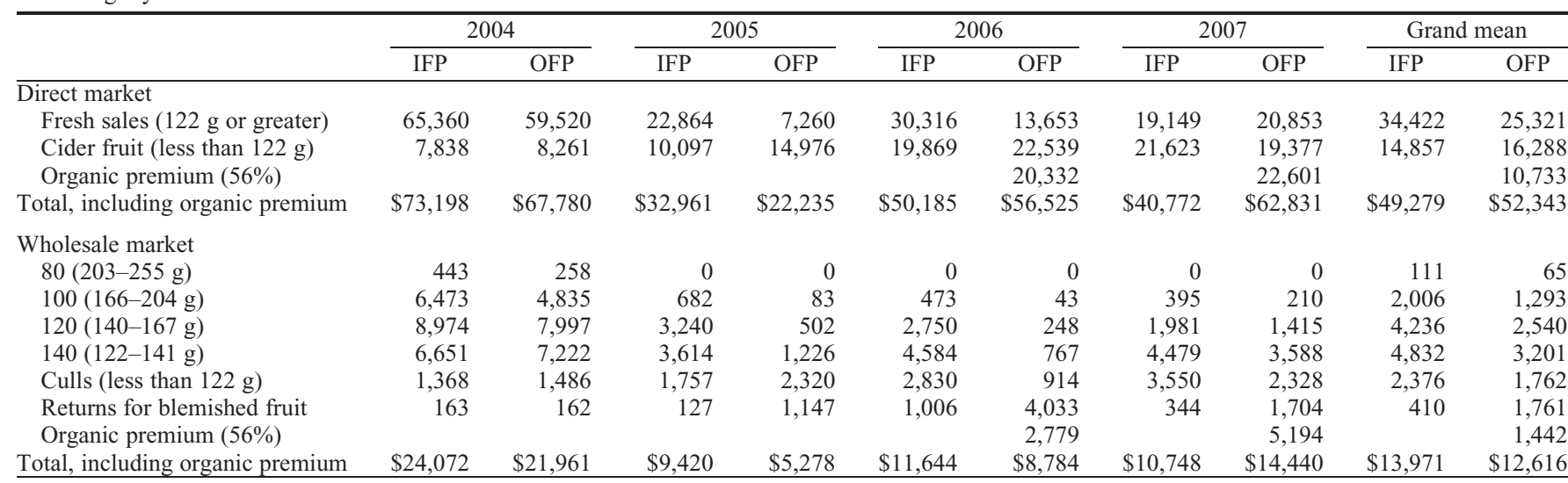

${ }^{2}$ Direct market prices were derived from interviews with growers in central New York. Wholesale prices were derived from published prices for 'Empire' apples grown in the Hudson River Valley, NY, and sold from October through December (the timeframe that 'Liberty' is commonly marketed) at the Terminal Produce Co-operative Market in Hunts Point, NY. An average organic price premium of $56 \%$ was determined for eight different cultivars (without regard to origin, color grade, size, or month of sale) in the Boston produce terminal during 2006 and 2007.

treatments, which contributed to premature fruit drop and small fruit size. For both treatments, follow-up hand-thinning was necessary each June to eliminate double or triple fruit set on many spurs. The lowest yields for both treatments were recorded in 2005 when adverse weather (a bloom-time frost and abnormally hot temperatures the week after chemical thinning materials were applied) caused a substantial amount of premature fruit drop. Greater IFP yield efficiencies and crop densities suggested that yield potential would be greater under IFP management if the incidence of preharvest fruit drop could be reduced. The smaller IFP fruit size in 2007 was attributed to the high crop load that year and to premature fall leaf drop of undetermined causation that was less severe in the OFP trees.

This premature leaf abscission was associated with extensive leaf blotch resembling that was reported for 'Golden Delicious' and its progeny (Rosenberger, 2004). Consultation with plant pathologists and physiologists suggested two possible causes for this problem. The first was that the usually nonpathogenic and ubiquitous epiphytic yeast, Aureobasidium pullulans, became pathogenic under the specific environmental conditions that occurred in 2007 (Andrews et al., 2002). If the causal agent was A. pullulans, then perhaps the broad-spectrum activity of lime sulfur was able to suppress that yeast more effectively in OFP than the strobilurinanilide mix used in IFP. The second hypothesis was that high ozone levels damaged the leaves but the kaolin clay treatments provided some leaf protection for the OFP trees.
Jones (1963) showed that tobacco leaves treated with kaolin clay incurred only slight damage when exposed to as much as $0.9 \mu \mathrm{g}$ ozone $/ \mathrm{m}^{3}$ atmosphere, whereas untreated leaves incurred damage at $0.4 \mu \mathrm{g} \cdot \mathrm{m}^{-3}$. Kaolin clay (as well as other particulate substances) may also act as a catalyst for the decomposition of ozone some distance away from the leaf surface, thereby not harming living tissue (Jones, 1963). The use of kaolin clay as an ozone protectant would be a novel application for this material (Glenn and Puterka, 2005).

Leaf nutrient concentrations. The plant nutrient management regime included ground and foliar fertilizer applications for both systems but was not sufficient for optimal tree nutrition in this study. Although the farm management rarely applies $\mathrm{N}$ to this orchard, additional $\mathrm{N}$ fertilizer applications may have improved the productivity of both treatments in this experiment. Trees in both systems remained at the low end of recommended ranges for leaf $\mathrm{N}$ in mature apple trees in New York during the last 3 years of this study (Stiles and Reid, 1991). N deficiency symptoms were evident in leaves from both systems. Although greater leaf nutrient levels were often found in OFP than in IFP trees, low levels of $\mathrm{K}, \mathrm{Ca}, \mathrm{Mg}, \mathrm{Mn}, \mathrm{Fe}, \mathrm{Cu}, \mathrm{B}$, and $\mathrm{Zn}$ existed in both systems. Organic apple growers in New York have reported problems with maintaining adequate leaf nutrient levels, possibly as a result of uncontrolled weed competition (Schupp, 2004). Although the Wonder Weeder cultivator provided more effective and convenient weed control compared with the Rinieri cultivator and others used in New York organic orchards, there were extended periods when weeds were present under OFP trees and likely competitive for nutrients and water. Decreased tree $\mathrm{N}$ status may also have contributed to the small OFP fruit size in our study.

The high Al levels observed in the OFP leaves were probably caused by the kaolin clay applications, because this product is based on aluminosilicates $\left[\mathrm{Al}_{4} \mathrm{Si}_{4} \mathrm{O}_{10}(\mathrm{OH})_{8}\right]$. The leaf samples were triple-washed with detergent before ICP analysis, so even greater Al levels probably existed in the field. However, foliar Al toxicity was not observed, and neither fruit nor soil samples had elevated $\mathrm{Al}$ concentrations.

Cullage assessment. Zehnder et al. (2007) suggested that organic pest control should rely on cultural practices, vegetation management, and the release of biocontrol agents before using insecticides to establish an agroecosystem equilibrium, after which biological processes and controls can provide adequate control of key pests. Organic principles postulate that this can be attained during the 3-year transition from conventional production. For some agroecosystems, primarily annual crops in arid regions, this may be an achievable equilibrium (Letourneau and Goldstein, 2001; Pimentel et al., 2005). However, in our test apple orchard, pest damage to OFP-grown apples remained high and was caused by a greater number of species compared with IFP. Four years may not have been long enough or the test plots may not have been large enough for a biocontrol equilibrium to be attained, but it is also possible that for organic orchards in New 
York, the dynamic equilibrium among trees, resources, pests, and biological control processes is well above economic damage thresholds for commercial fruit growers. Abandoned apple trees in the Northeastern landscape typically sustain greater than $95 \%$ pest damage to the fruit (Harrington and Good, 2000). In the absence of effective biocontrols, apple growers need to rely on cultural methods and crop protectants to produce adequate yields of marketable fruit.

The pest control practices used in OFP were not as effective as those used for IFP, causing arthropod and fruit finish defects to be substantially greater under OFP management. The organically approved insecticides that we used tended to have either low toxicity (e.g., kaolin clay) or relatively short residual activity (e.g., Bt, $\mathrm{CpGV}$, pyrethrum). Furthermore, with the materials used for OFP pest control, frequent applications were needed and sprays had to be precisely timed with each pest's most susceptible life-cycle phase. This differed in IFP management, in which pest control materials have longer residual activity and efficacy in the orchard. In our study, cultural practices were more crucial for OFP than IFP. For example, more fruit with visible pest damage (usually from internal Lepidopterans and European apple sawflies) had to be removed during handthinning in OFP compared with IFP to reduce the incidence of arthropod damage at harvest.

Over the course of this study, it was necessary to continually adapt and modify OFP pest control strategies. Kaolin clay is one of the few materials available for plum curculio and apple maggot control in New York organic orchards (Reissig et al., 2002). At the start of our study, kaolin clay was applied 11 times (from petal fall through August) for control of these pests. However, the clay residue was difficult to remove from harvested fruit and the season-long applications were prohibitively expensive. In response, we reduced by $50 \%$ the number of kaolin clay applications in 2005. However, under this lower input insect management program, arthropods damaged $\approx 25 \%$ of OFP-grown fruit-an 8.6-fold increase from 2004. Therefore, in the third year, pyrethrum was applied for plum curculio control, an additional spinosad application and sticky traps were used in late summer for apple maggot control, $\mathrm{CpGV}$ was added to improve control of codling moth, and PMD was intensified for internal Lepidoptera pests. Compared with 2005, these efforts reduced damage to OFP fruit, but they did not significantly decrease OFP costs. In contrast, arthropod control in the IFP system remained relatively similar and effective during the 4 years of this experiment, and fruit damage in IFP was comparable with conventionally managed New York orchards (Harrington and Good, 2000).

Cosmetic blemishes, including russet and scarfskin, were significantly greater on fruit grown under OFP. We attributed this superficial blemishing to the lime sulfur used for fruit thinning. Lime sulfur is one of the more effective materials for chemical fruit thinning in OFP, but under certain weather conditions such as the high relative humidity after lime sulfur was applied in 2006, it can cause considerable cosmetic blemishes (Holb et al., 2003; McArtney et al., 2006; Noordijk and Schupp, 2003). Characterized by a whitish or cloudy hue on the surface of fruit, scarfskin was also most likely caused by abiotic factors, including lime sulfur, but also possibly kaolin clay (Beach, 1905). Russeting and scarfskin are generally cosmetic and do not damage the interior fruit flesh. However, these damages can significantly reduce consumer acceptance and fruit value. Under USDA grading standards, much of this fruit would be considered suitable only for juice (Federal Register, 2002). Organic growers may have to cope with fruit finish problems resulting from chemical thinning sprays during years with unfavorable weather in New York.

Problems with SB/FS and other "summer diseases" have been reported previously in Northeastern orchards where scab-resistant cultivars were grown with no or minimal fungicide treatments (Ellis et al., 1998; Merwin et al., 1994; Rosenberger et al., 1996). Although 'Liberty' is resistant to the major fungal pests of apple trees, it is not resistant to $\mathrm{SB} / \mathrm{FS}$. In 2006, the SB/FS control program in OFP consisted of two applications of a potassium bicarbonate product (Kaligreen ${ }^{\circledR}$; Toagosei Co., Ltd., Tokyo, Japan) after 270 leaf-wetting hours postpetal fall (Brown and Sutton, 1995). Potassium bicarbonate has reportedly provided adequate control of SB/FS in previous studies (Andrews et al., 2001), but this material was ineffective in our study during 2006, a year with abundant rainfall. In 2007, a year with less rainfall, lime sulfur applications also failed to provide adequate control of SB/FS in the OFP system. In contrast, during those same years, stobilurin and anilide fungicides provided good control of SB/FS in the IFP system (Table 3). New fungicide development has lagged relative to the newer insecticides for OFP, and advances in this area could improve the feasibility of OFP in humid fruit-growing regions.

Environmental Impact Quotient. The EIQ is one of the most widely accepted models for assessing nontarget effects of pesticides (Greitens and Day, 2007; Levitan et al., 1995). In our study, the large field use EIQ ratings for OFP were largely attributed to lime sulfur and fish oil used for fruit thinning and kaolin clay used for pest control. These materials are currently considered to be the best management practices for OFP, but they must be used in large quantities to be efficacious (Noordijk and Schupp, 2003; Reissig et al., 2002). The field use algorithm in the EIQ model attributes linearly greater negative impacts to products that are used in larger quantities, independent of their presumed toxicity, following the toxicological dictum "the dose makes the poison" (Dushoff et al., 1994).

Both lime sulfur and oil (whether fish or petroleum) have potential negative effects on plant health, beneficial insects, and farm workers (http://extoxnet.orst.edu/), which helps explain the relatively large field use EIQ ratings for these products. Although kaolin clay is an inert compound used in medicine, toothpaste, cosmetics, and as a food additive, according to the material safety data sheet, it can potentially cause respiratory, dermal, and eye irritations (as a result of its small particle size) in pesticide applicators and other agricultural workers. In our experiment, repeated high-dose applications of kaolin clay in OFP led to both positive and negative effects. Kaolin clay provided adequate control of plum curculio and some other insect pests (Glenn and Puterka, 2005), but unlike the report by Thomas et al. (2004), kaolin was not effective against $\mathrm{SB} / \mathrm{FS}$ in our study. We also observed that predacious mite populations were suppressed by kaolin applications (data not shown), as reported by others (Benedict, 2005; Markó et al., 2006). Additionally, kaolin clay comprised a substantial portion of the OFP costs, and the clay residues were difficult to remove from fruit-potentially a deterrent to the marketing of organic apples. Unlike Glenn et al. (2005), consistent improvement in color grade resulting from the kaolin clay applications was not observed in our study.

Strictly speaking, potential negative environmental impacts of different pest control systems cannot be inferred solely from any of the presently available environmental assessment models, none of which include potential environmental impacts of fossil fuel use, fertilizers, water resource use, soil management systems, or economic externalities (Levitan et al., 1995). For the new putative "reduced-risk" pesticides, there may also be potential unforeseen issues that will emerge after decades of use. For example, heavy reliance on neonicotinoids in IFP, and spinosads in OFP, may lead to pest resistance and control failures for both of these systems (Nauen and Denholm, 2005; Shono and Scott, 2003).

Variable costs of production. Organic fruit production systems are reported to be more expensive than conventional and integrated systems (Reganold et al., 2001), and this was borne out in our experiment. For comparative purposes, recent reports have shown that a conventional insecticide program in New York costs $\$ 363 /$ ha in low pest pressure sites and up to $\$ 647 /$ ha in high pest pressure orchards, indicating that without PMD, the $\$ 451 /$ ha for insecticides and miticides in our IFP system was midrange compared with conventional New York orchards (Agnello et al., 2005; White et al., 2008). However, when PMD was included, IFP costs were $\$ 732 / \mathrm{ha}$. In contrast, the $\$ 945 /$ ha costs for OFP insecticides, miticides, and kaolin clay materials (or \$1169/ha with PMD) were well above what commercial apple growers in New York typically spend for arthropod pest control. The high cost for OFP was largely the result of kaolin clay. Although use of this material was reduced over the course of our experiment, the use of 
other insecticides such as spinosad, pyrethrum, and $\mathrm{CpGV}$ increased. With a sustained market price premium for organic apples, these pest control costs could still be acceptable, but as organic tree fruit production increases in other regions (Granatstein and Kirby, 2008), the price premium for organic apples may diminish below the level of profitability for New York growers.

The greatest single input cost for the IFP system was the bark mulch application. Bark mulch is not widely used in IFP or conventional New York orchards, but it has been shown to improve soil quality and nutrient availability while reducing herbicide inputs (Yao et al., 2005). Bark mulch was not applied to the OFP system because it would have interfered with surface weed cultivation and because occasional use of herbicides is necessary to control perennial weeds in the bark mulch. Additionally, we did not want to incorporate this mulch (a high $\mathrm{C}$, low $\mathrm{N}$ material) into the topsoil because it might immobilize and therefore limit $\mathrm{N}$ availability to the trees. The use of bark mulch cut herbicide applications from two per year in 2005, to none the next year, to just one application in 2007-substantially reducing herbicide use in IFP.

Potential market value of fruit. Although cumulative yields were not significantly different in these two systems, pest damage and small fruit size affected their potential market value. In 2005, both systems had reduced revenues as a result of bloom-time frost, but the OFP system had significant insect damage as well. For the direct market, if we assumed a higher market threshold for surface blemishes caused by insects, physiological factors, or disease, then in all years but 2005, the blemished fruit from the OFP system might have been more acceptable and comparable with the IFP system (Table $3)$. However, this questionable assumption may not be realized in the marketplace. A recent study indicated that consumers were much less willing to pay a premium for blemished organic apples from local orchards when they were offered other unblemished, organic apples that were cosmetically comparable to conventional fruit (Yue et al., 2006). Nonetheless, a direct market system offers greater potential for OFP-grown fruit because of less stringent grading standards. Cider is often made from culls and sold directly by growers in the eastern United States, and this potential use for blemished fruit also made OFP more feasible. Because 'Liberty' fruits are relatively small in size, the estimated market values in this report could differ for other disease resistant apples such as 'Enterprise', a larger-sized fruit (Merwin et al., 1994).

Conventional wholesale packinghouses often reject apples with trace amounts of internally damaged fruit, and the amount of damage recorded for OFP apples in 2005 could have eliminated that entire harvest from the wholesale marketplace. Likewise in 2006, when a majority of the organic fruit was cosmetically damaged, a commercial packinghouse might have rejected that fruit unless there was a shortage of organic apples. However, if local direct sales are not an option, then eastern U.S. organic apples will have to compete with those grown in arid climates more favorable to OFP. Lastly, the greater costs without a price premium in the marketplace during the 36-month transition period can be an impediment for the adoption of OFP.

At present, there is no price premium for IFP fruit in the mainstream U.S. market, and this has discouraged growers from adopting this system (Carroll and Robinson, 2004). An IFP system is considered to have additional risk for fruit growers because it is based on newer materials that are costlier and less well understood than older-generation pesticides (e.g., organophosphates, carbamates, and pyrethroids). Additionally, cultural practices such as bark mulch and pheromone mating disruption, which are encouraged under IFP management, are more expensive than the current standard conventional practices. Major supermarket corporations that adopted IFP and GlobalGAP certification as preconditions for their wholesale apple suppliers drove the wide-scale adoption of IFP in western Europe and New Zealand. It may take similar market forces to increase U.S. grower interest and participation in IFP certification programs (Loureiro et al., 2001).

In conclusion, under both IFP and OFP systems, it was possible to produce marketable yields of apples in New York's humid growing conditions. These systems both used a holistic approach that included soil quality improvement, cultural practices for arthropod control, and an intensive IPM program. However, this study evaluated a scab-resistant cultivar, and although there are several effective and economical fungicides approved for IFP, an apple orchard of disease-susceptible cultivars for OFP would have to rely on repeated applications of sulfur, lime sulfur, and copper for disease control. The use of these materials would undermine the sustainability of OFP for apple growers in the northeastern United States. In New York State, IFP could be widely implemented for apple production, but OFP may be most feasible for small to midsized direct market operations.

\section{Literature Cited}

Agnello, A. (ed.). 2007. 2008 pest management guidelines for commercial tree-fruit production. Cornell Coop. Ext., Ithaca, NY.

Agnello, A., J. Nyrop, H. Reissig, and D. Straub. 2005. Reduced-risk pest management in apples using pheromone disruption and a selective pesticide program. Report to the USDA Risk Avoidance and Mitigation Project (RAMP). 15 Jan. 2010. <http://www.nysaes.cornell.edu/ent/ faculty/agnello/pdf/RAMP $\% 202005 \% 20 \mathrm{NY} \%$ 20Full\%20Report.pdf>.

Agnello, A.M., W.H. Reissig, J. Kovach, and J.P. Nyrop. 2003. Integrated apple pest management in New York State using predatory mites and selective pesticides. Agr. Ecosyst. Environ. 94:183-195.

Andrews, J.H., J.K. O'Mara, and P.S. McManus. 2001. Methionine-riboflavin and potassium bicarbonate-polymer sprays control apple flyspeck and sooty blotch. Plant Health Prog. 10.1094/PHP-2001-0706-01-RS.

Andrews, J.H., R.N. Spear, and E.V. Nordheim. 2002. Population biology of Aureobasidium pullulans on apple leaf surfaces. Can. J. Microbiol. 48:500-513.

Anonymous. 2002. Guidelines for integrated production of pome fruit. 3rd Edition. IOBC WPRS Bull. 25

Beach, S.A. 1905. The apples of New York. Vol. 1. J.B. Lyons Company, Albany, NY.

Benedict, C.A. 2005. Non-target impact of kaolin on phytophagous (Acari: Tetranychidae) and predatory mites (Acari: Phytoseiidae) in an apple agro-ecosystem. M.S. Thesis, Univ. of Vermont, Burlington, VT.

Brown, E.M. and T.B. Sutton. 1995. An empirical model for predicting the first symptoms of sooty blotch and flyspeck of apples. Plant Dis. 79:1165-1168.

Carroll, J.E. and T.L. Robinson. 2004. The New York State apple IFP, our 'most friendly practices.' New York Fruit Qrtly. 12:5-8.

Carroll, J.E. and T.L. Robinson (eds.). 2006. New York integrated fruit production protocol for apples. New York's Food and Life Sci. Bull. 158.

Croft, B.A. and S.C. Hoyt (eds.). 1983. Integrated management of insect pests of pome and stone fruits. John Wiley \& Sons, Inc., New York, NY.

Delate, K., A. McKern, J.T.S. Walker, R. Volz, A White, V. Bus, D. Rogers, L. Cole, N. How, S. Guernsey, and J. Johnston. 2008. Organic apple production in two humid regions: Comparing progress in pest management strategies in Iowa and New Zealand. HortScience 43: $12-21$.

Dushoff, J., B. Caldwell, and C.L. Mohler. 1994. Evaluating the environmental effect of pesticides: A critique of the Environmental Impact Quotient. Amer. Entomol. Fall:180-184.

Ellis, M.A., D.C. Ferree, R.C. Funt, and L.V. Madden. 1998. Effects of an apple-scab resistant cultivar on use patterns of inorganic and organic fungicides and economics of disease control. Plant Dis. 82:428-433.

Federal Register. 2000. National Organic Program; final rule. 7 CFR part 65:80547-80596.

Federal Register. 2002. United States standards for grades of apples. 7 CFR part 51:300-321.

Glenn, D.M., S. Drake, J.A. Abbot, G.J. Puterka, and P. Gundrum. 2005. Season and cultivar influence the fruit quality response of apple cultivars to particle film treatments. HortTechnology 15:249-253.

Glenn, D.M. and G.J. Puterka. 2005. Particle films: A new technology for agriculture. Hortic. Rev. (Am. Soc. Hortic. Sci.) 31:1-44.

Granatstein, D. and E. Kirby. 2008. Washington State, national, and international status of organic tree fruit (2007). 15 Jan. 2010. <http://organic. tfrec.wsu.edu/OrganicStats/OrgTreeFruitReport_ Feb08.pdfs

Greitens, T.J. and E. Day. 2007. An alternative way to evaluate the environmental effects of integrated pest management: Pesticide risk indicators. Renew. Agr. Food Syst. 22:213222.

Harrington, E. and G. Good. 2000. Crop profiles: Apples in New York. 15 Jan. 2010. <http:// pmep.cce.cornell.edu/fqpa/crop-profiles/apples. html $>$.

Holb, I.A., P.F. De Jong, and B. Heijne. 2003. Efficacy and phytotoxicity of lime sulphur in organic apple production. Ann. Appl. Biol. 142:225-233.

Jones, J.L. 1963. Ozone damage: Protection for plants. Science 140:1317-1318. 
Jönsson, А. and H. Nybom. 2006. Consumer evaluation of scab-resistant cultivars in Sweden. Agr. Food Sci. 15:388-401.

Kalra, Y.P. (ed.). 1998. Handbook of reference methods for plant analysis. CRC Press, Boca Raton, FL.

Kovach, J., C. Petzoldt, J. Degni, and J. Tette. 1992. A method to measure the environmental impact of pesticides. New York's Food and Life Sci. Bull. 139.

Lamb, R.G., H.S. Aldwinckle, R.D. Way, and D.E. Terry. 1978. Liberty, a new disease resistant apple. New York's Food and Life Sci. Bull. 73.

Letourneau, D.K. and B. Goldstein. 2001. Pest damage and arthropod community structure in organic vs. conventional tomato production in California. J. Appl. Ecol. 38:557-570.

Levitan, L., I. Merwin, and J. Kovach. 1995. Assessing the relative environmental impacts of agricultural pesticides: The quest for a holistic method. Agr. Ecosyst. Environ. 55:153-168.

Loureiro, M.L., J.J. McCluskey, and R.C. Mittelhammer. 2001. Assessing consumer preferences for organic, eco-labeled, and regular apples. J. Agr. Resource Econ. 26:404-416.

MacHardy, W.E. 2000. Current status of IPM in apple orchards. Crop Prot. 19:801-806.

Markó, V., L.H.M. Blommers, S. Bogya, and H. Helsen. 2006. The effect of kaolin treatments on phytophagous and predatory arthropods in the canopies of apple trees. J. Fruit Ornamental Plant Res. 14(suppl. 3):79-87.

McArtney, S., J. Palmer, S. Davies, and S. Seymour. 2006. Effects of lime sulfur and fish oil on pollen tube growth, leaf photosynthesis and fruit set in apple. HortScience 41:357-360.

Merwin, I., G. Peck, and E. Vollmer. 2005. Organic orchards in the Northeast: Progress, practices, and problems, p. 61-62. In: Granatstein, D. and A. Azarenko (eds.). Proc. 3rd Natl. Organic Tree Fruit Res. Symp. Washington State Univ. Tree Fruit Res. and Ext. Ctr., Wenatchee, WA.

Merwin, I.A., S.K. Brown, D.A. Rosenberger, D.R. Cooley, and L.P. Berkett. 1994. Scabresistant apples for the northeastern United States: New prospects and old problems. Plant Dis. 78:4-10.

Nauen, R. and I. Denholm. 2005. Resistance of insect pests to neonicotiniod insecticides: Current status and future prospects. Arch. Insect Biochem. Physiol. 58:200-215.
Noordijk, H. and J. Schupp. 2003. Organic postbloom apple thinning with fish oil and lime sulfur. HortScience 38:690 (abstr).

Peck, G.M. 2009. Integrated and organic production of 'Liberty' apple: Two agroecosystems from the ground up. Ph.D. Diss., Cornell Univ., Ithaca, NY.

Peck, G.M., P.K. Andrews, J.P. Reganold, and J.K Fellman. 2006. Apple orchard productivity and fruit quality under organic, conventional, and integrated management. HortScience 41:99-107.

Peck, G.M., I.A. Merwin, C.B. Watkins, K.W. Chapman, and O.I. Padilla-Zakour. 2009. Maturity and quality of 'Liberty' apple fruit under integrated and organic production systems are similar. HortScience 44:1382-1389.

Pimentel, D., P. Hepperly, J. Hanson, D. Douds, and R. Seidel. 2005. Environmental, energetic, and economic comparisons of organic and conventional farming systems. Bioscience 55:573-582.

Prokopy, R.J., R.E. Mittenthal, and S.E. Wright. 2003. Evaluation of trap deployment patterns for behavioral control of apple maggot flies (Dipt., Tephritidae). J. Appl. Ent. 127:276-281.

Reganold, J.P., J.D. Glover, P.K. Andrews, and H.R. Hinman. 2001. Sustainability of three apple production systems. Nature 410:926-930.

Reissig, H., R. Straub, and A. Agnello. 2002. Surround ${ }^{\mathrm{TM}}$ : A realistic choice for control of insects in organic apple orchards in the Northeastern United States? New York Fruit Qrtly. 10:5-8.

Rosenberger, D. 2004. Necrotic leaf blotch of Golden Delicious apples. Scaffolds Fruit J. 13. 23 Aug. 2009. <http://www.nysaes.cornell. edu/ent/scafolds/2004/040823.html $>$.

Rosenberger, D.A., C.A. Engle, and F.W. Meyer. 1996. Effects of management practices and fungicides on sooty blotch and flyspeck diseases and productivity of Liberty apples. Plant Dis. 80:798-803.

Rull, J. and R.J. Prokopy. 2004. Revisiting withintree trap positioning for apple maggot fly (Dipt., Tephritidae) behavioural control. J. Appl. Ent. 128:195-199.

Schupp, J. 2004. Mineral nutrition management for organic fruit production. New York Fruit Qtrly. 12:31-34.

Shono, T. and J.G. Scott. 2003. Spinosad resistance in the housefly, Musca domestica, is due to a recessive factor on autosome 1 . Pestic. Biochem. Physiol. 75:1-7.
Smith, T.J. 1999. Report on the development of and use of Cougerblight $98 \mathrm{C}-\mathrm{a}$ situation specific fire blight risk assessment model for apple and pear. Acta Hort. 489:429-436.

Stiles, W.C. and W.S. Reid. 1991. Orchard nutrition management. Cornell Coop. Ext. Info. Bull. 219.

Suckling, D.M., J.T.S. Walker, and C.H. Wearing. 1999. Ecological impacts of three pest management systems in New Zealand apple orchards. Agr. Ecosyst. Environ. 73:129-140.

Thomas, A.L., M.E. Muller, B.R. Dodson, M.R. Ellersieck, and M. Kaps. 2004. A kaolin-based particle film suppresses certain insect and fungal pests while reducing heat stress in apples. J. Amer. Pomol. Soc. 58:42-51.

USDA AMS. 2008. Fruit and Vegetable Market News (FVMN) web site. 15 Jan. 2010. <http:// www.marketnews.usda.gov/portal/fv>.

USDA ERS. 2008. organic farmgate and wholesale prices. 15 Jan. 2010. < http://www.ers.usda.gov/ Data/OrganicPrices/>.

USDA NASS. 2006. Agricultural chemical usage 2005 fruit summary. Washington, DC.

USDA NASS. 2008. The USDA NASS New York Field Office 'Fact Finders for Agriculture.' Fruit reports. 15 Jan. 2010. <http://www.nass.usda. gov/Statistics_by_State/New_York/Publications/ Statistical_Reports/fruit.htm>.

White, G.B. 2008. Cost of establishment and production of Vinifera grapes in the Finger Lakes Region of New York-2007. Cornell Univ. Appl. Econ. Mgt. Ext. Bull. 2008-05

White, G.B., A.M. DeMarree, and J. Neyhard. 2008. Fruit farm business summary: Lake Ontario Region New York 2007. Cornell Univ. Appl. Econ. Mgt. Ext. Bull. 2008-19

Yao, S., I.A. Merwin, G.W. Bird, G.A. Abawi, and J.E. Thies. 2005. Orchard floor management practices that maintain vegetative or biomass groundcover stimulate soil microbial activity and alter soil microbial community composition. Plant Soil 271:377-389.

Yue, C., F. Alfnes, and H.H. Jensen. 2006. Discounting spotted apples: Investigating consumers' willingness to accept cosmetic damage in an organic product. Ctr. Agr. Rural Dev. Iowa State University, Ames, IA. Working Paper 06-WP 436.

Zehnder, G., G.M. Gurr, S. Kühne, M.R. Wade, S.D. Wratten, and E. Wyss. 2007. Arthropod pest management in organic crops. Annu. Rev. Entomol. 52:57-80. 